\title{
Recent advances in the understanding and management of cystic fibrosis pulmonary exacerbations [version 1; peer
}

\section{review: 3 approved]}

\author{
Kate Skolnik1, Bradley S. Quon (iD)2 \\ ${ }^{1}$ Division of Respirology, Department of Medicine, University of Calgary, Calgary, AB, Canada \\ ${ }^{2}$ Centre for Heart Lung Innovation, St Paul's Hospital, Department of Medicine, University of British Columbia, Vancouver, BC, \\ Canada
}

V1 First published: 14 May 2018, 7(F1000 Faculty Rev):575
https://doi.org/10.12688/f1000research.13926.1

Latest published: 14 May 2018, 7(F1000 Faculty Rev):575

https://doi.org/10.12688/f1000research.13926.1

\section{Abstract}

Pulmonary exacerbations are common events in cystic fibrosis and have a profound impact on quality of life, morbidity, and mortality. Pulmonary exacerbation outcomes remain poor and a significant proportion of patients fail to recover their baseline lung function despite receiving aggressive treatment with intravenous antibiotics. This focused review provides an update on some of the recent advances that have taken place in our understanding of the epidemiology, pathophysiology, diagnosis, and management of pulmonary exacerbations in cystic fibrosis as well as direction for future study.

\section{Keywords}

cystic fibrosis, exacerbations, treatment

\section{Open Peer Review}

Approval Status

1

2

3

version 1

14 May 2018

Faculty Reviews are review articles written by the prestigious Members of Faculty Opinions. The articles are commissioned and peer reviewed before publication to ensure that the final, published version is comprehensive and accessible. The reviewers who approved the final version are listed with their names and affiliations.

\footnotetext{
1. John J. LiPuma, University of Michigan Medical School, Ann Arbor, USA

2. Martin J Wildman, University of Sheffield, Sheffield, UK

3. Patrick A. Flume, Medical University of South Carolina, Charleston, USA

Any comments on the article can be found at the end of the article.
} 
Corresponding author: Bradley S. Quon (Bradley.Quon@hli.ubc.ca)

Author roles: Skolnik K: Conceptualization, Writing - Original Draft Preparation, Writing - Review \& Editing; Quon BS:

Conceptualization, Supervision, Writing - Original Draft Preparation, Writing - Review \& Editing

Competing interests: No competing interests were disclosed.

Grant information: BSQ receives salary support from the Michael Smith Foundation for Health Research and from Cystic Fibrosis Canada.

The funders had no role in study design, data collection and analysis, decision to publish, or preparation of the manuscript.

Copyright: @ 2018 Skolnik K and Quon BS. This is an open access article distributed under the terms of the Creative Commons Attribution License, which permits unrestricted use, distribution, and reproduction in any medium, provided the original work is properly cited.

How to cite this article: Skolnik $\mathrm{K}$ and Quon BS. Recent advances in the understanding and management of cystic fibrosis pulmonary exacerbations [version 1; peer review: 3 approved] F1000Research 2018, 7(F1000 Faculty Rev):575

https://doi.org/10.12688/f1000research.13926.1

First published: 14 May 2018, 7(F1000 Faculty Rev):575 https://doi.org/10.12688/f1000research.13926.1 


\section{Introduction}

Despite improvements in lung function and nutritional outcomes for individuals with cystic fibrosis (CF) over the past decade, pulmonary exacerbation (PEx) remains common. In 2016, according to US Cystic Fibrosis Foundation Patient Registry data, one in three patients required at least one course of intravenous (IV) antibiotics to treat a $\mathrm{PEx}^{1}$. Exacerbations have a profound impact on the morbidity and quality of life of individuals with $\mathrm{CF}$, and unfortunately PEx outcomes remain suboptimal with poor recovery of baseline lung function following PEx treatment ${ }^{2}$. As a result, efforts are under way within the $\mathrm{CF}$ research community to improve the management of these clinically impactful events. The focus of this review is to summarize some of the recent advances that have taken place in our understanding of the epidemiology, pathophysiology, diagnosis, and management of $\mathrm{PEx}$ in $\mathrm{CF}$ and to provide direction for future study.

\section{Pulmonary exacerbation definition and diagnosis}

Although there is general agreement on the importance of PEx, there is no consensus definition of what constitutes a PEx by $\mathrm{CF}$ clinicians, researchers, and the broader CF community. However, an ideal or consensus PEx definition (or scoring system) is likely to remain elusive without a gold standard to compare it against. Varying PEx definitions employed in the $\mathrm{CF}$ literature have been a major impediment to research progress and have inherently confounded many of the studies included in this review. This caveat must be kept in mind while reading this review because of the potential lack of specificity about what is being studied and discussed.

In an attempt to move toward a consensus PEx definition, the EuroCFCare Working group has recommended the use of a modified Fuchs criteria to define a PEx which includes the need for additional antibiotic treatment (oral or IV) and a recent change of at least two of the following six criteria: change in sputum volume or color; increased cough; increased fatigue, malaise, or lethargy; anorexia or weight loss; decrease in pulmonary function by $10 \%$ or more or radiographic changes; and increased dyspnea $^{3}$. However, this definition has been criticized by some experts in the field because the diagnosis of PEx should be independent of the physician's decision to treat and pulmonary function testing limits the age range of patients assessed. Some recent pediatric trials have used the PEx definition employed in the Early Pseudomonas Infection Control (EPIC) trial, which consists of one major criterion (decrease in forced expiratory volume in one second $\left[\mathrm{FEV}_{1}\right]$ at least $10 \%$ from baseline with the previous 6 months; oxygen saturation less than $90 \%$ on room air or at least $5 \%$ decline from baseline; new lobar infiltrates or atelectasis on chest X-ray; hemoptysis) or two minor symptoms/signs (increased respiratory rate; new or increased adventitial sounds on lung exam; weight loss of at least $5 \%$ in the previous 6 months; increased cough; decreased exercise tolerance; increased chest congestion or change in sputum) for at least 5 days or with significant symptom severity ${ }^{4}$.

Despite the lack of a consensus PEx definition, recent studies have focused on strategies to diagnose CF PEx earlier given the risk of poor outcomes. In the Standardized Treatment of
Pulmonary Exacerbations (STOP) study, a multi-site observational study of patients with CF treated with IV antibiotics in hospital, most patients (85\%) described symptoms more than 7 days before admission and nearly one-third (32\%) had symptoms more than 21 days beforehand ${ }^{5}$. Less than half $(48 \%)$ of these individuals received oral antibiotics prior to admission, suggesting that certain patients may have prolonged symptoms in keeping with PEx but, due to delays in diagnosis, are not started on treatment. For these reasons, there has been a recent focus on home monitoring of symptoms and lung function to promote earlier PEx detection and treatment to prevent irreversible lung damage.

A multi-center study from the Netherlands examining electronic home monitoring of symptoms and lung function for early PEx detection confirmed a change in symptoms at least 4 weeks prior to PEx diagnosis in most patients, and further symptom deterioration in the 2 weeks prior to PEx diagnosis 6 . However, a large multi-center randomized trial recently conducted in the US demonstrated that although electronic home monitoring of symptoms and spirometry is feasible and leads to earlier and more frequent diagnoses of PEx compared with usual care, this strategy does not lead to less lung function lost over 1 year? An earlier diagnosis in the home-monitoring arm led to more frequent use of oral (versus IV) antibiotics compared with the usual-care arm (67\% versus 43\%), and this might have resulted in a higher rate of non-recovery of $\mathrm{FEV}_{1} \%$ predicted to within $5 \%$ of baseline ( $47 \%$ versus $21 \%$ ) due to a less robust response to oral antibiotic treatment ${ }^{7}$. The authors concluded that identifying PEx earlier may not be sufficient and that future studies must also find better approaches to treatment of exacerbations once they are detected. However, there may still be utility for home monitoring for early PEx detection, particularly for individuals who are poor perceivers of their symptoms, have frequent exacerbations, or reside in rural areas which may delay access to care.

\section{Pulmonary exacerbation epidemiology \\ Pulmonary exacerbation prevalence}

The proportion of patients requiring at least one course of IV antibiotics per year has not decreased significantly over the past decade $^{1}$. Although this might seem concerning in light of the overall improvements in lung function observed over the same time period, this appears to be driven by a lower threshold among clinicians to diagnose and treat $\mathrm{PEx}^{8}$. Some important studies have highlighted the wide variability in the recognition and treatment of PEx between CF clinics and individual CF physicians in both the US and the $\mathrm{UK}^{9,10}$. A multi-center study in the UK demonstrated higher IV antibiotic use among centers with higher baseline $\mathrm{FEV}_{1} \%$ predicted ${ }^{10}$, whereas an older multicenter US study found variability among centers with respect to care (those with a higher median $\mathrm{FEV}_{1} \%$ predicted had more frequent monitoring and antibiotics) ${ }^{9}$. These findings have led to quality improvement initiatives to reduce variability ${ }^{11,12}$.

\section{Pulmonary exacerbation risk factors}

In order to prevent PEx and their associated sequelae, there has been a great deal of interest in identifying the risk factors for future PEx. VanDevanter et al. investigated factors associated 
with increased risk of PEx requiring IV antibiotics ${ }^{13}$. The study found that, out of numerous clinical variables, including sputum microbiology and treatment characteristics, the strongest risk factor for a PEx requiring IV antibiotic therapy was the occurrence of a PEx requiring IV antibiotics in the preceding year ${ }^{13}$. Not surprisingly, individuals with three or more exacerbations had the highest risk of future PEx compared with those with one or two exacerbations ${ }^{13}$.

\section{Pulmonary exacerbation outcomes}

With regard to PEx treatment outcomes, exacerbations treated with oral antibiotics are often considered to be milder events, whereas those treated with IV antibiotics are considered to represent more severe events. However, labeling a PEx on the basis of route of antibiotic treatment (oral versus IV) is limited and potentially biased, since factors other than PEx severity (based on symptoms, inflammatory markers, or lung function decline or a combination of these) may influence the decision of antibiotic route. For instance, IV antibiotics may be chosen on the basis of medication allergies/intolerances, bacterial resistance to oral antibiotics, or other non-disease severity-related factors (such as psychosocial issues or insurance coverage).

In support of the concept that exacerbations treated with oral antibiotics may not represent mild events, based on a recent retrospective study using the Toronto CF database from 2000 to 2014 , nearly $20 \%$ of exacerbations treated with oral antibiotics did not recover to within $90 \%$ of baseline $\mathrm{FEV}_{1} \%$ predicted within 3 months of treatment ${ }^{14}$. Furthermore, the greater the number of cumulative oral antibiotic-treated events over the study period, the steeper the rate of lung function decline ${ }^{14}$. Consequently, close follow-up post-treatment is warranted to ensure recovery, and patients with repeated exacerbations treated with oral antibiotics may warrant more intensive treatment with IV antibiotics.

Even among patients who receive aggressive treatment with IV antibiotics, PEx outcomes remain suboptimal. Based on CF registry data from both the US and Canada, $25 \%$ of individuals who experience exacerbations fail to recover baseline lung function as defined by $90 \%$ of baseline within 3 months of treatment ${ }^{2,15}$. Factors independently associated with non-response included female sex; malnourishment; pancreatic insufficiency; persistent infection with Pseudomonas aeruginosa, Burkholderia cepacia complex, or methicillin-resistant Staphylococcus aureus; allergic bronchopulmonary aspergillosis; larger drop in $\mathrm{FEV}_{1} \%$ predicted at the time of PEx; and longer time from baseline spirometric assessment ${ }^{2}$.

It is important to recognize that the proportion of nonresponders can vary substantially depending on the definition of "response" used. For example, when a definition of FEV improvement to $90 \%$ of baseline is employed, $25 \%$ of exacerbations are classified as non-responders, whereas an improvement to $100 \%$ of baseline yields a non-response rate as high as $60 \%{ }^{16}$. Furthermore, it should be noted that up to $25 \%$ of patients in the STOP trial had their best lung function at the time of PEx diagnosis and therefore a sizeable proportion of patients will be defined as responders even before treatment has started, leading to underestimation of treatment non-response. Most studies have used the best $\mathrm{FEV}_{1}$ in the 3 months following the end of IV antibiotic treatment as the follow-up $\mathrm{FEV}_{1}$, since lung function improvement can continue following the completion of IV antibiotics and therefore end-of-treatment values can underestimate rates of response.

\section{Pulmonary exacerbation triggers}

Viral respiratory tract infections have been estimated to be associated with about $50 \%$ of exacerbations and this might explain why exacerbations are more frequent during the winter months ${ }^{17-19}$. The most common viral pathogens include rhinovirus, respiratory syncytial virus (RSV) (in children), parainfluenza, influenza, adenovirus, coronavirus, and coxsackie/ echovirus $^{17,18,20,21}$. It was previously hypothesized that viruses could increase bacterial density of chronic colonizing organisms; however, a recent study has refuted this, demonstrating no change in $P$. aeruginosa density between viral- versus non-viral-associated $\mathrm{PEx}^{17}$. Interestingly, anti-viral interferon signaling in response to RSV infection is capable of inducing $P$. aeruginosa biofilm formation through dysregulated iron homeostasis and this could represent a putative mechanism for viral-triggered PEx but warrants further study ${ }^{22}$. It is also important to note that although there appears to be a strong association between viruses and PEx, this does not necessarily imply a causal relationship, as studies have demonstrated the presence of virus even when patients are well (suggesting asymptomatic nasopharyngeal carriage $)^{23,24}$.

While non-viral-associated exacerbations were also believed to be the result of increased bacterial density of the chronic primary pathogen, recent studies have challenged this dogma. Multiple studies have demonstrated no significant changes in bacterial density from stable to PEx state ${ }^{25-28}$. Although decreases in bacterial density are observed following antimicrobial treatment, these effects are transient and are poorly predictive of clinical response ${ }^{28-30}$. Research has shown that $\mathrm{CF}$ airway infections are polymicrobial and that interactions between these microbes may increase or decrease pathogenicity ${ }^{31}$. It is believed by some experts that organisms (such as anaerobes) can interact with the primary pathogen to enhance virulence without a change in density ${ }^{31}$. For example, a recent study evaluating airway bacterial communities with 16S rRNA sequencing found no significant differences in bacterial community diversity or density between paired stable and PEx samples, but there was a change in community structure for a subgroup of patients ${ }^{26}$. Furthermore, the absolute and relative abundance of Gemella spp. increased in the majority of samples from stable to PEx state, and this was most discriminative of health status (stable versus $\mathrm{PEx})^{26}$.

Air pollution is also an important trigger of PEx, and a seminal study linking the US CF National Registry to the US Environmental Protection Agency Aerometric Information Retrieval System demonstrated a significant association between annual average exposure to particulate matter and risk of $\mathrm{PEx}^{32}$. A 
recent case-crossover analysis confirmed this finding and found that increased exposure to particulate matter less than $10 \mathrm{~mm}$ in diameter $\left(\mathrm{PM}_{10}\right)$, nitrogen dioxide, and ozone was associated with increased need for oral or IV antibiotics for PEx on the day of exposure $^{33}$.

\section{Pulmonary exacerbation treatment}

\section{Treatment endpoints}

In general, the goal of PEx treatment is to improve symptoms and recover lost lung function ${ }^{34}$. Based on the STOP study, physicians identified recovery of lung function as the primary objective of treatment in $53 \%$ of exacerbations compared with improvement of symptoms in $43 \%$ of exacerbations ${ }^{5}$. There is considerable variability as to what constitutes an acceptable threshold for $\mathrm{FEV}_{1}$ improvement before antibiotics can be stopped. Based on the STOP study, the mean FEV improve- $^{-}$ ment was 9\% (standard deviation [SD] 10\%) predicted at the end of IV antibiotic treatment and 7\% (SD 11\%) predicted at day 28. Patients with baseline $\mathrm{FEV}_{1}$ of more than $50 \%$ predicted had a greater increase in $\mathrm{FEV}_{1} \%$ predicted from admission to day 28 than patients with baseline $\mathrm{FEV}_{1}$ less than $50 \%$ predicted (10\% versus $3 \%)$. Interestingly, there was discordance between physician treatment targets in terms of lung function improvement and evaluation of treatment success. Based on the STOP study, $84 \%$ of clinicians deemed PEx treatment successful, although only $61 \%$ of patients achieved at least $90 \%$ of their target $\mathrm{FEV}_{1}$ by the end of IV antibiotic therapy ${ }^{35}$.

The treatment endpoint for an individual patient is likely to depend on the primary motivating factor for treatment. In the STOP study, a significant proportion of patients (20\%) were admitted for IV antibiotics despite presenting with their best recorded $\mathrm{FEV}_{1} \%$ predicted in the prior 6 months ${ }^{5}$. In these cases, symptoms were the primary driver for treatment and symptom resolution would be the most appropriate endpoint of treatment response. In general, exacerbations are more likely to be defined based on symptoms alone in children compared with adults (in whom drop in lung function may be more likely to occur $)^{36}$. The most widely used daily scoring system for monitoring of respiratory/infectious symptoms during PEx treatment is the Cystic Fibrosis Respiratory Symptom Diary - Chronic Respiratory Infection Symptom Score (CFRSD-CRISS) ${ }^{37}$. Total scores range from 0 to 100 , and an 11-point decrease is considered clinically significant ${ }^{38}$. Based on STOP, CFRSDCRISS decreased by 26.1 (95\% confidence interval 23.8-28.3) and $83 \%$ of patients achieved a clinically significant improvement ${ }^{35}$. However, it should be noted that the CFRSD-CRISS has limitations in that it has been used and evaluated in a research setting only and has not been accepted by the US Food and Drug Administration as a validated endpoint.

Whereas short-term goals of PEx treatment are to recover lost lung function and improve symptoms, long-term treatment goals generally are to prevent recurrent events and reduce the rate of lung function decline. Interestingly, a recent study found that symptom improvement (that is, CFRSD-CRISS score) in response to PEx treatment is poorly predictive of long-term response in terms of recovery of baseline lung function at 3 months or time to next IV antibiotics; however, immediate $\mathrm{FEV}_{1}$ response ( $>10 \%$ relative improvement) was predictive of recovery of baseline $F E V_{1}$ by 3 months ${ }^{39}$. Synthesizing all of this evidence suggests that a composite outcome that includes symptom and lung function improvement might be the most appropriate endpoint in prospective studies examining PEx therapies.

\section{Treatment controversies}

Based on the 2009 Cystic Fibrosis Foundation PEx treatment guidelines, there was insufficient evidence to provide recommendations on a number of decisions related to PEx management, including site of treatment (inpatient versus outpatient), antibiotic duration, and the use of adjunctive therapies (such as systemic steroids) (Figure 1) $)^{40}$. Since this publication, observational studies have provided additional insights into these treatment controversies and randomized controlled trials (RCTs) are ongoing or have been recently completed.

\section{Site of treatment}

There are some circumstances in which admission to hospital for optimal PEx treatment is clearly indicated (such as hypoxia, complications such as pneumothorax, or co-morbidities such as renal failure), but in many situations outpatient treatment with IV antibiotics appears to be a reasonable option. However, in deciding on the optimal treatment setting, an important factor is not just safety and feasibility but also whether one treatment setting is more efficacious than the other. One small randomized, two-factor, mixed-design comparative study involving 17 adults with $\mathrm{CF}$ has been performed and showed similar results for most outcome measures for home and hospital treatment ${ }^{41}$. Owing to selection bias, the results of a larger RCT of the two treatment settings may not be generalizable and will be challenging to interpret because of lack of blinding, attrition bias, high rates of crossover, and lack of standardized resources for home care at various care centers ${ }^{40}$.

A small, single-center retrospective study examined 143 PEx events from 50 patients and compared hospital with home IV therapy ${ }^{42}$. The baseline characteristics between the two groups were similar; however, the hospitalized group had a greater improvement in lung function with a shorter duration of therapy ${ }^{42}$. In a recent observational study of pediatric $\mathrm{CF}$ patients from the Epidemiologic Study of CF (ESCF), those with an acute decline in lung function were more likely to recover to within $90 \%$ of baseline $\mathrm{FEV}_{1}$ when receiving treatment as an inpatient versus outpatient ${ }^{43}$. However, observational studies involving treatment are often confounded by indication bias. In other words, patients are not randomly assigned and therefore the intensity of treatments is not standardized between comparisons; ultimately, patients in hospital might receive more intensive treatments. Another recent study that also used the ESCF employed statistical approaches to control for indication bias and found that PEx with a greater proportion of days treated as an inpatient (versus outpatient) with IV antibiotics was more likely to lead to return of $\mathrm{FEV}_{1} \%$ predicted to at least $90 \%$ of baseline ${ }^{44}$. Although this observational study is not definitive (as there was likely residual confounding), the benefits of inpatient PEx treatment are likely due to multiple factors other than the 


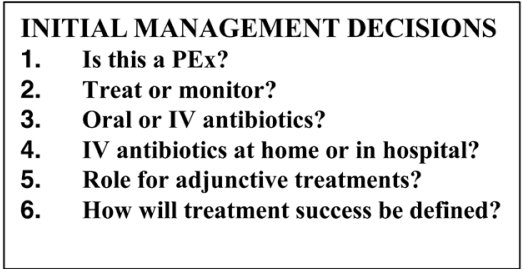

\section{INTERIM TREATMENT DECISIONS \\ 1. Is the patient responding or not? \\ 2. Do antibiotics need to be modified? \\ 3. Are adjunctive treatments now needed? \\ 4. Can antibiotics be stopped early on day 10 ?}

\section{END OF TREATMENT DECISIONS}

1. Has the patient responded to treatment?

2. Does the patient warrant an extension of treatment?

3. How can the next PEx be prevented?

4. How closely does the patient need to be followed post-treatment?

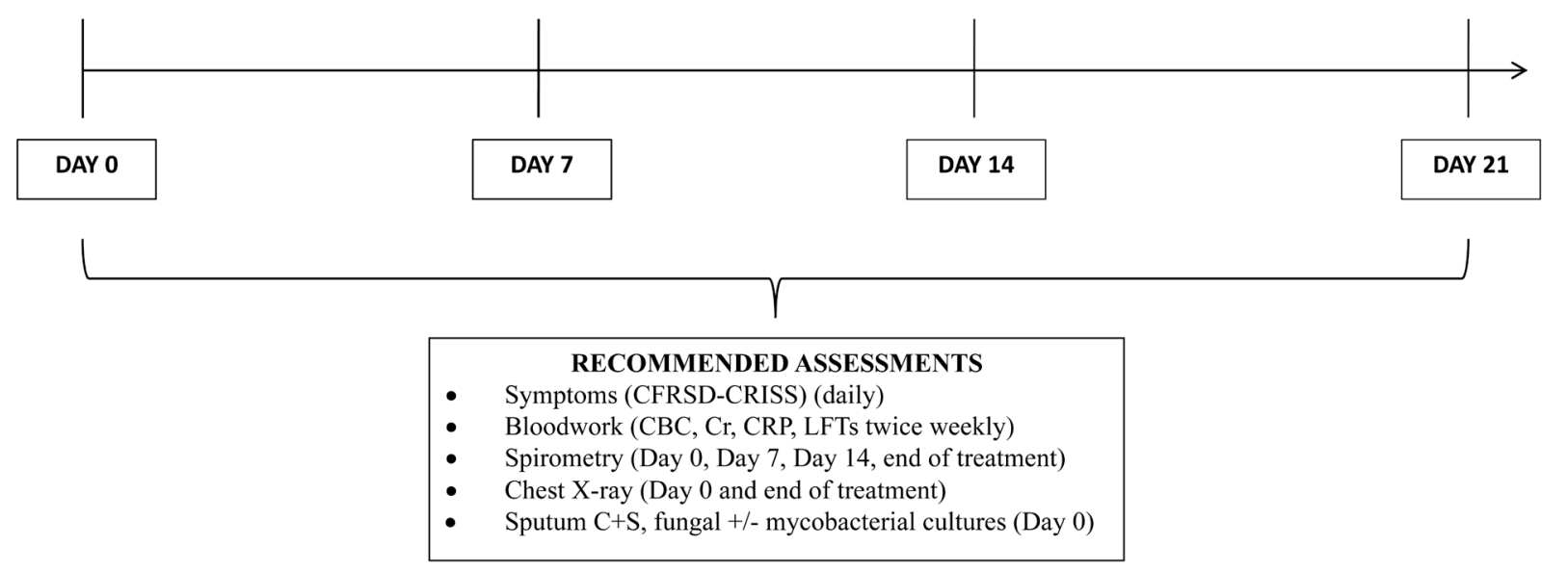

Figure 1. Outline of pulmonary exacerbation treatment decisions. CBC, complete blood count; CFRSD-CRISS, Cystic Fibrosis Respiratory Symptom Diary-Chronic Respiratory Infection Symptom Score; Cr, creatinine; CRP, C-reactive protein; C+S, culture and sensitivity; IV, intravenous; LFT, liver function test; PEx, pulmonary exacerbation.

IV antibiotics alone, including improved medication adherence, better nutrition, real-time adjustment of adjunct therapies, increased airway clearance treatments, and increased rest.

Ultimately, the decision regarding treatment site should be made based on careful consideration of patient factors (with a low threshold for inpatient treatment if there are concerns about patient reliability and adherence to airway clearance therapies, sufficient home supports, or more complex IV antibiotic regimens $)^{40}$.

\section{Duration of antibiotics}

For historical reasons, CF exacerbations are typically treated for 14 days. Based on the STOP study, the mean duration of treatment was 15.9 (SD 6.0) days; however, $11 \%$ of patients received treatment for 10 days or less and $60 \%$ received treatment for more than 14 days with no significant differences in duration for individuals younger than 18 years old versus those older than 18 years old ${ }^{35}$. There have been no randomized studies examining the duration of IV antibiotics to provide evidence-based recommendations. An observational study that used the US CF Foundation Patient Registry found that $\mathrm{FEV}_{1} \%$ predicted plateaus by day 10 of treatment and duration of treatment did not influence time until next $\mathrm{PEx}^{45}$. More recent retrospective data on the benefits of prolonging antibiotic treatment are conflicting, as a study using the Toronto CF Database found improved outcomes with longer treatment duration (>14 days) whereas a larger study using data from the ESCF did not find a significant association between treatment duration and rate of recovery of $\mathrm{FEV}_{1} \%$ predicted to within $90 \%$ of baseline ${ }^{16,44}$. However, as in observational studies of treatment setting, interpretation is limited by indication bias, since patient factors influence treatment duration (patients with lower lung function received longer treatment courses) $)^{45}$. A large multi-center study (STOP2) is under way in the US examining IV antibiotic duration since it was identified as the most important research question by $\mathrm{CF}$ physicians and patients/caregivers. A divergent trial design is being used and randomly assigns patients to 10 versus 14 days or 14 versus 21 days of IV antibiotics depending on initial symptom and lung function response by day $7^{46}$.

\section{Adjunctive therapies}

A recent study evaluating inpatient PEx treatment practices for pediatric $\mathrm{CF}$ patients across the US demonstrated wide variability in the use of adjunctive treatments, including hypertonic saline, azithromycin, and systemic corticosteroids ${ }^{47}$. Several adjunct therapies for the treatment of CF PEx have recently been evaluated or are currently under investigation. These adjunct therapies function by either optimizing airway clearance or reducing airway inflammation.

Although nebulized hypertonic saline is well established as a strategy for PEx prevention ${ }^{48}$, it has only recently been studied as an adjunct during PEx treatment. In an RCT, Dentice et al. compared PEx outcomes in individuals randomly assigned to nebulized $7 \%$ hypertonic saline versus taste-masked control thrice daily ${ }^{49}$. The majority of patients in both groups had either never or only intermittently used hypertonic saline prior to enrollment. Although this study did not meet its primary 
endpoint in terms of reduced length of hospital stay, there was greater improvement in symptoms and higher rates of $\mathrm{FEV}_{1}$ recovery in the hypertonic saline group ${ }^{49}$. Furthermore, the study provided reassurance that nebulized hypertonic saline was safe to start (or increase) in the context of acute $\mathrm{PEx}^{49}$.

Another recent study examined doxycycline as an adjunct therapy for CF PEx, acting as a small-molecule inhibitor of matrix metalloproteinase-9 (MMP-9), which has been implicated in $\mathrm{CF}$ airway pathophysiology, particularly during $\mathrm{PEx}^{50,51}$. This single-center RCT randomly assigned $39 \mathrm{CF}$ patients with PEx requiring inpatient care to either doxycycline $100 \mathrm{mg}$ orally twice daily or placebo for 8 days in addition to standard patient care (IV antibiotics and increased airway clearance) ${ }^{52}$. Compared with the placebo group, the doxycycline group had a significant decrease in total and active sputum MMP-9 levels, improved protease-antiprotease imbalance in the airways, greater improvement in $\mathrm{FEV}_{1} \%$ predicted from admission, and longer time to next $\mathrm{PEx}^{52}$. Whether doxycycline has direct effects on dysregulated protease activity versus indirect effects due to changes in the microbiome remains unclear, but this single-center study has set the stage for a larger multi-center placebo-controlled $\mathrm{RCT}^{52}$.

Although systemic corticosteroids are used in up to $20 \%$ of $\mathrm{CF}$ exacerbations ${ }^{35,39}$, there is limited evidence to support their use $\mathrm{e}^{40}$. Just one small pilot placebo-controlled study involving 24 patients ( $\geq 10$ years old) examined oral prednisone $(2 \mathrm{mg} / \mathrm{kg}$ per day up to a maximum of $60 \mathrm{mg}$ divided twice daily) versus placebo for the first 5 days as an adjunct to standard-of-care PEx treatment ${ }^{53}$. Although there was no significant effect on lung function, symptom improvement, or sputum inflammatory markers compared with placebo, the study was underpowered to evaluate treatment effects ${ }^{53}$. A multi-center, randomized, placebo-controlled trial evaluating prednisone-referred to as the Prednisone in CF Pulmonary Exacerbation (PIPE) study - is under way and involves six pediatric and adult $\mathrm{CF}$ clinics across Canada. This study will provide more definitive evidence regarding the role of systemic corticosteroids during PEx. Patients receiving IV antibiotic treatment and who have not responded to standard of care alone by day 7 (that is, not recovered at least $90 \%$ of their baseline $\mathrm{FEV}, \%$ predicted) will be randomly assigned to prednisone $(2 \mathrm{mg} / \mathrm{kg}$ per day up to a maximum of $60 \mathrm{mg}$ divided twice daily) or placebo for 7 days.

\section{Pulmonary exacerbation biomarkers}

In the field of $\mathrm{CF}$, there is tremendous interest in identifying a biomarker that could aid in the earlier diagnosis of a CF PEx or assist in tracking the response to PEx treatment or do both. Earlier diagnosis can allow for the timelier initiation of treatment, which might result in better PEx outcomes. A reliable biomarker of response to treatment could also identify non-responders earlier during the course of treatment so that therapies can be modified or extended accordingly.

The majority of biomarkers in relation to PEx have focused on inflammation in the sputum and blood ${ }^{54,55}$. Although sputum is an attractive option because it most closely reflects airway inflammation, its evaluation has been limited to research studies because it can be challenging to collect and process in clinical laboratories. Several sputum biomarkers of inflammation, including interleukin-8 (IL-8), neutrophil elastase (NE), calprotectin, club cell secretory protein (CCSP), and MMP-9, have been investigated during $\mathrm{PEx}^{56-59}$. Although most of these sputum biomarkers change significantly from stable to PEx state or following PEx treatment, the results have been variable between studies. Sputum NE appears to be promising, as a recent study by Waters et al. found that a decrease in sputum NE was independently associated with response to IV antibiotic treatment at day 14 and higher NE levels at day 14 were associated with greater risk of subsequent $\mathrm{PEx}^{57}$.

Among blood biomarkers, numerous markers of inflammation have been evaluated as recently reviewed ${ }^{60}$. Serum C-reactive protein (CRP) and calprotectin have been the most extensively studied in the context of PEx and offer the most promise for clinical use ${ }^{54}$. All studies evaluating CRP and calprotectin in $\mathrm{CF}$ have demonstrated significant reductions in levels from beginning to end of PEx treatment ${ }^{54,56,58}$. However, a recent study demonstrated that CRP increases in $25 \%$ of patients during the first 5 days of IV antibiotic treatment prior to decreasing, thus making it a challenging biomarker to monitor early response to treatment ${ }^{61}$. Individuals with persistently elevated CRP and calprotectin levels following IV antibiotics also experience a shorter time to re-exacerbation ${ }^{57,62}$.

Although several candidate biomarkers that correlate with clinical outcomes during PEx treatment have been identified, it remains unclear whether their prospective use can influence treatment decisions to improve PEx outcomes and whether they add incremental utility to monitoring of symptoms and lung function alone.

\section{Future directions}

Although small but incremental progress is being made in our understanding of PEx in $\mathrm{CF}$ on the basis of observational studies, there remain several gaps in knowledge and a need for more interventional studies to guide evidence-based practice. The CF community is eagerly awaiting the results of the aforementioned RCTs evaluating various IV antibiotic treatment durations and the adjunctive use of systemic corticosteroids and doxycycline, as these have the potential to improve PEx outcomes. In addition, a greater understanding of the sequence of events leading to a PEx at a molecular level is required to improve PEx phenotyping and to guide the development of more targeted treatments.

\section{Competing interests}

The authors declare that they have no competing interests.

\section{Grant information}

BSQ receives salary support from the Michael Smith Foundation for Health Research and from Cystic Fibrosis Canada.

The funders had no role in study design, data collection and analysis, decision to publish, or preparation of the manuscript. 
1. Cystic Fibrosis Foundation Patient Registry: 2015 Annual Report. Bethesda, Maryland. 2016 Cystic Fibrosis Foundation. Reference Source

2. Sanders DB, Bittner RC, Rosenfeld M, et al.: Failure to recover to baseline pulmonary function after cystic fibrosis pulmonary exacerbation. Am J Respir Crit Care Med. 2010; 182(5): 627-32. PubMed Abstract | Publisher Full Text | Free Full Text

3. Bilton D, Canny G, Conway S, et al:: Pulmonary exacerbation: towards a definition for use in clinical trials. Report from the EuroCareCF Working Group on outcome parameters in clinical trials. J Cyst Fibros. 2011; 10(Suppl 2): S79-81.

PubMed Abstract | Publisher Full Text

4. Treggiari MM, Rosenfeld M, Mayer-Hamblett N, et al:: Early anti-pseudomonal acquisition in young patients with cystic fibrosis: rationale and design of the EPIC clinical trial and observational study'. Contemp Clin Trials. 2009; 30(3): 256-68.

PubMed Abstract | Publisher Full Text | Free Full Text

5. F Sanders DB, Solomon GM, Beckett VV, et al:: Standardized Treatment of Pulmonary Exacerbations (STOP) study: Observations at the initiation of intravenous antibiotics for cystic fibrosis pulmonary exacerbations. $J$ Cyst Fibros. 2017; 16(5): 592-9.

PubMed Abstract | Publisher Full Text | Free Full Text | F1000 Recommendation

6. $\quad F$ van Horck M, Winkens B, Wesseling $G$, et al.: Early detection of pulmonary exacerbations in children with Cystic Fibrosis by electronic home monitoring of symptoms and lung function. Sci Rep. 2017; 7(1): 12350. PubMed Abstract | Publisher Full Text | Free Full Text | F1000 Recommendation

7. $\mathrm{F}$ Lechtzin N, Mayer-Hamblett N, West NE, et al:: Home Monitoring of Patients with Cystic Fibrosis to Identify and Treat Acute Pulmonary Exacerbations. eICE Study Results. Am J Respir Crit Care Med. 2017; 196(9): 1144-51. PubMed Abstract | Publisher Full Text | Free Full Text | F1000 Recommendation

8. VanDevanter DR, Elkin EP, Pasta DJ, et al.: Changing thresholds and incidence of antibiotic treatment of cystic fibrosis pulmonary exacerbations, 1995-2005. J Cyst Fibros. 2013; 12(4): 332-7.

PubMed Abstract | Publisher Full Text

9. Johnson C, Butler SM, Konstan MW, et al.: Factors influencing outcomes in cystic fibrosis: a center-based analysis. Chest. 2003; 123(1): 20-7. PubMed Abstract | Publisher Full Text

10. $\mathrm{F}$ Hoo ZH, Campbell MJ, Curley R, et al:: Do cystic fibrosis centres with the lowest $\mathrm{FEV}_{1}$ still use the least amount of intravenous antibiotics? A registrybased comparison of intravenous antibiotic use among adult CF centres in the UK. J Cyst Fibros. 2017; pii: S1569-1993(17)30916-5.

PubMed Abstract | Publisher Full Text | F1000 Recommendation

11. Kraynack NC, Gothard MD, Falletta LM, et al:: Approach to treating cystic fibrosis pulmonary exacerbations varies widely across US CF care centers. Pediatr Pulmonol. 2011; 46(9): 870-81.

PubMed Abstract | Publisher Full Text

12. Kraynack NC, McBride JT: Improving care at cystic fibrosis centers through quality improvement. Semin Respir Crit Care Med. 2009; 30(5): 547-58. PubMed Abstract | Publisher Full Tex

13. F VanDevanter DR, Morris NJ, Konstan MW: IV-treated pulmonary exacerbations in the prior year: An important independent risk factor for future pulmonary exacerbation in cystic fibrosis. J Cyst Fibros. 2016; 15(3): 372-9. PubMed Abstract | Publisher Full Text | Free Full Text | F1000 Recommendation

14. F Stanojevic S, McDonald A, Waters V, et al:: Effect of pulmonary exacerbations treated with oral antibiotics on clinical outcomes in cystic fibrosis. Thorax. 2017; 72(4): 327-32. PubMed Abstract | Publisher Full Text | F1000 Recommendation

15. Waters V, Atenafu EG, Salazar JG, et al:: Chronic Stenotrophomonas maltophilia infection and exacerbation outcomes in cystic fibrosis. J Cyst Fibros. 2012; 11(1): 8-13.

PubMed Abstract | Publisher Full Text

16. Waters V, Stanojevic S, Klingel M, et al.: Prolongation of antibiotic treatment for cystic fibrosis pulmonary exacerbations. J Cyst Fibros. 2015; 14(6): 770-6. PubMed Abstract | Publisher Full Text

17. F Chin M, De Zoysa M, Slinger R, et al:: Acute effects of viral respiratory tract infections on sputum bacterial density during CF pulmonary exacerbations. J Cyst Fibros. 2015; 14(4): 482-9.

PubMed Abstract | Publisher Full Text | F1000 Recommendation

18. Asner $\mathrm{S}$, Waters $\mathrm{V}$, Solomon $\mathrm{M}$, et al:: Role of respiratory viruses in pulmonary exacerbations in children with cystic fibrosis. J Cyst Fibros. 2012; 11(5): 433-9. PubMed Abstract | Publisher Full Text

19. Wat $D$, Gelder $C$, Hibbitts $S$, et al:: The role of respiratory viruses in cystic fibrosis. J Cyst Fibros. 2008; 7(4): 320-8.

PubMed Abstract | Publisher Full Text

20. Goffard A, Lambert V, Salleron J, et al.: Virus and cystic fibrosis: rhinoviruses are associated with exacerbations in adult patients. J Clin Virol. 2014; 60(2): 147-53.

PubMed Abstract | Publisher Full Text

21. F Somayaji R, Goss $\mathrm{CH}$, Khan U, et al:: Cystic Fibrosis Pulmonary Exacerbations Attributable to Respiratory Syncytial Virus and Influenza: A Population-Based Study. Clin Infect Dis. 2017; 64(12): 1760-7. PubMed Abstract | Publisher Full Text | Free Full Text | F1000 Recommendation

22. Hendricks MR, Lashua LP, Fischer DK, et al:: Respiratory syncytial virus infection enhances Pseudomonas aeruginosa biofilm growth through dysregulation of nutritional immunity. Proc Natl Acad Sci U S A. 2016; 113(6): 1642-7. PubMed Abstract | Publisher Full Text | Free Full Text

23. de Almeida $\mathrm{MB}$, Zerbinati $\mathrm{RM}$, Tateno $\mathrm{AF}$, et al:: Rhinovirus $\mathbf{C}$ and respiratory exacerbations in children with cystic fibrosis. Emerg Infect Dis. 2010; 16(6): 996-9.

PubMed Abstract | Publisher Full Text | Free Full Text

24. Stelzer-Braid S, Johal H, Skilbeck K, et al:: Detection of viral and bacterial respiratory pathogens in patients with cystic fibrosis. J Virol Methods. 2012; 186(1-2): 109-12. PubMed Abstract | Publisher Full Text

25. Stressmann FA, Rogers GB, Marsh $\mathrm{P}$, et al.: Does bacterial density in cystic fibrosis sputum increase prior to pulmonary exacerbation? J Cyst Fibros. 2011; 10(5): 357-65.

PubMed Abstract | Publisher Full Text

26. Carmody LA, Zhao J, Schloss PD, et al: Changes in cystic fibrosis airway microbiota at pulmonary exacerbation. Ann Am Thorac Soc. 2013; 10(3): 179-87. PubMed Abstract | Publisher Full Text | Free Full Text

27. Fothergill $\mathrm{JL}$, Ledson MJ, Walshaw MJ, et al:: Comparison of real time diagnostic chemistries to detect Pseudomonas aeruginosa in respiratory samples from cystic fibrosis patients. J Cyst Fibros. 2013; 12(6): 675-81. PubMed Abstract | Publisher Full Text

28. F Lam JC, Somayaji R, Surette MG, et al:: Reduction in Pseudomonas aeruginosa sputum density during a cystic fibrosis pulmonary exacerbation does not predict clinical response. BMC Infect Dis. 2015; 15: 145 PubMed Abstract | Publisher Full Text | Free Full Text | F1000 Recommendation

29. F Ordoñez CL, Henig NR, Mayer-Hamblett N, et al.: Inflammatory and microbiologic markers in induced sputum after intravenous antibiotics in cystic fibrosis. Am J Respir Crit Care Med. 2003; 168(12): 1471-5. PubMed Abstract | Publisher Full Text | F1000 Recommendation

30. Tunney MM, Klem ER, Fodor AA, et al:: Use of culture and molecular analysis to determine the effect of antibiotic treatment on microbial community diversity and abundance during exacerbation in patients with cystic fibrosis. Thorax 2011; 66(7): 579-84.

PubMed Abstract | Publisher Full Text

31. Nicod LP, Kolls JK: Chair's Summary: Mechanisms of Exacerbation of Lung Diseases. Ann Am Thorac Soc. 2015; 12 Suppl 2: S112-4. PubMed Abstract | Free Full Text

32. Goss $\mathrm{CH}$, Newsom SA, Schildcrout JS, et al:: Effect of ambient air pollution on pulmonary exacerbations and lung function in cystic fibrosis. Am J Respir Crit Care Med. 2004; 169(7): 816-21.

PubMed Abstract | Publisher Full Text

33. Goeminne PC, Kiciński M, Vermeulen F, et al.: Impact of air pollution on cystic fibrosis pulmonary exacerbations: a case-crossover analysis. Chest. 2013; 143(4): 946-54.

PubMed Abstract | Publisher Full Text

34. Stenbit AE, Flume PA: Pulmonary exacerbations in cystic fibrosis. Curr Opin Pulm Med. 2011; 17(6): 442-7.

PubMed Abstract

35. F West NE, Beckett VV, Jain R, et al.: Standardized Treatment of Pulmonary Exacerbations (STOP) study: Physician treatment practices and outcomes for individuals with cystic fibrosis with pulmonary Exacerbations. J Cyst Fibros. 2017; 16(5): 600-6.

PubMed Abstract | Publisher Full Text | F1000 Recommendation

36. Waters V, Ratjen F: Pulmonary Exacerbations in Children with Cystic Fibrosis. Ann Am Thorac Soc. 2015; 12 Suppl 2: S200-6.

PubMed Abstract

37. Goss $\mathrm{CH}$, Edwards TC, Ramsey BW, et al:: Patient-reported respiratory symptoms in cystic fibrosis. J Cyst Fibros. 2009; 8(4): 245-52. PubMed Abstract | Publisher Full Text

38. Goss $\mathrm{CH}$, Caldwell E, Gries KNL, et al:: Validation of a novel patient-reported respiratory symptoms instrument in cystic fibrosis: CFRSD-CRISS. Pediatr Pulmonol. 2013: A251.

39. $\mathrm{F}$ Heltshe SL, Goss CH, Thompson V, et al:: Short-term and long-term response to pulmonary exacerbation treatment in cystic fibrosis. Thorax. 2016; 71(3): 223-9.

PubMed Abstract | Publisher Full Text | Free Full Text | F1000 Recommendation 
40. Flume PA, Mogayzel PJ Jr, Robinson KA, et al.: Cystic fibrosis pulmonary guidelines: treatment of pulmonary exacerbations. Am J Respir Crit Care Med. 2009; 180(9): 802-8.

PubMed Abstract | Publisher Full Text

41. Wolter JM, Bowler SD, Nolan PJ, et al:: Home intravenous therapy in cystic fibrosis: a prospective randomized trial examining clinical, quality of life and cost aspects. Eur Respir J. 1997; 10(4): 896-900. PubMed Abstract

42. Nazer D, Abdulhamid I, Thomas R, et al:: Home versus hospital intravenous antibiotic therapy for acute pulmonary exacerbations in children with cystic fibrosis. Pediatr Pulmonol. 2006; 41(8): 744-9.

PubMed Abstract | Publisher Full Text

43. F Morgan WJ, Wagener JS, Pasta DJ, et al:: Relationship of Antibiotic Treatment to Recovery after Acute FEV $_{1}$ Decline in Children with Cystic Fibrosis. Ann Am Thorac Soc. 2017; 14(6): 937-42.

PubMed Abstract | Publisher Full Text | F1000 Recommendation

44. F Schechter MS, VanDevanter DR, Pasta DJ, et al:: Treatment Setting and Outcomes of Cystic Fibrosis Pulmonary Exacerbations. Ann Am Thorac Soc. 2018; 15(2): 225-33

PubMed Abstract | Publisher Full Text | F1000 Recommendation

45. F Collaco JM, Green DM, Cutting GR, et al.: Location and duration of treatment of cystic fibrosis respiratory exacerbations do not affect outcomes. Am J Respir Crit Care Med. 2010; 182(9): 1137-43.

PubMed Abstract | Publisher Full Text | Free Full Text | F1000 Recommendation

46. F Heltshe SL, West NE, VanDevanter DR, et al.: Study design considerations for the Standardized Treatment of Pulmonary Exacerbations $2\left(\mathrm{STOP}_{2}\right)$ : A tria to compare intravenous antibiotic treatment durations in CF. Contemp Clin Trials. 2018: 64: 35-40. PubMed Abstract | Publisher Full Text | Free Full Text | F1000 Recommendation

47. F Cogen JD, Oron AP, Gibson RL, et al:: Characterization of Inpatient Cystic Fibrosis Pulmonary Exacerbations. Pediatrics. 2017; 139(2). pii: e20162642. PubMed Abstract | Publisher Full Text | Free Full Text | F1000 Recommendation

48. F Elkins MR, Robinson M, Rose BR, et al:: A controlled trial of long-term inhaled hypertonic saline in patients with cystic fibrosis. N Engl J Med. 2006; 354(3): 229-40.

PubMed Abstract | Publisher Full Text | F1000 Recommendation

49. F Dentice RL, Elkins MR, Middleton PG, et al:: A randomised trial of hypertonic saline during hospitalisation for exacerbation of cystic fibrosis. Thorax. 2016; 71(2): 141-7.

PubMed Abstract | Publisher Full Text | F1000 Recommendation

50. Gaggar A, Li Y, Weathington N, et al.: Matrix metalloprotease-9 dysregulation in lower airway secretions of cystic fibrosis patients. Am J Physiol Lung Cell Mol Physiol. 2007; 293(1): L96-L104.

PubMed Abstract | Publisher Full Text
51. Hanemaaijer R, Visser $\mathrm{H}$, Koolwijk $\mathrm{P}$, et al.: Inhibition of MMP synthesis by doxycycline and chemically modified tetracyclines (CMTs) in human endothelial cells. Adv Dent Res. 1998; 12(2): 114-8.

PubMed Abstract | Publisher Full Text

52. F Xu X, Abdalla T, Bratcher PE, et al:: Doxycycline improves clinical outcomes during cystic fibrosis exacerbations. Eur Respir J. 2017; 49(4): pii: 1601102. PubMed Abstract | Publisher Full Text | F1000 Recommendation

53. F Dovey M, Aitken ML, Emerson J, et al:: Oral corticosteroid therapy in cystic fibrosis patients hospitalized for pulmonary exacerbation: a pilot study. Chest. 2007; 132(4): 1212-8.

PubMed Abstract | Publisher Full Text | F1000 Recommendation

54. Shoki AH, Mayer-Hamblett N, Wilcox PG, et al:: Systematic review of blood biomarkers in cystic fibrosis pulmonary exacerbations. Chest. 2013; 144(5): 1659-70

PubMed Abstract | Publisher Full Text

55. Sagel SD, Chmiel JF, Konstan MW: Sputum biomarkers of inflammation in cystic fibrosis lung disease. Proc Am Thorac Soc. 2007; 4(4): 406-17. PubMed Abstract | Publisher Full Text | Free Full Text

56. Horsley AR, Davies JC, Gray RD, et al:: Changes in physiological, functional and structural markers of cystic fibrosis lung disease with treatment of a pulmonary exacerbation. Thorax. 2013; 68(6): 532-9. PubMed Abstract | Publisher Full Text

57. F Waters VJ, Stanojevic S, Sonneveld N, et al:: Factors associated with response to treatment of pulmonary exacerbations in cystic fibrosis patients. J Cyst Fibros. 2015; 14(6): 755-62.

PubMed Abstract | Publisher Full Text | F1000 Recommendation

58. Gray RD, Imrie M, Boyd AC, et al:: Sputum and serum calprotectin are useful biomarkers during CF exacerbation. J Cyst Fibros. 2010; 9(3): 193-8. PubMed Abstract | Publisher Full Text

59. Laguna TA, Williams CB, Brandy KR, et al:: Sputum club cell protein concentration is associated with pulmonary exacerbation in cystic fibrosis. $J$ Cyst Fibros. 2015; 14(3): 334-40

PubMed Abstract | Publisher Full Text | Free Full Text

60. F Scott LK, Toner R: Clinically Promising Biomarkers in Cystic Fibrosis Pulmonary Exacerbations. Lung. 2017; 195(4): 397-401. PubMed Abstract | Publisher Full Text | F1000 Recommendation

61. Sharma A, Kirkpatrick G, Chen V, et al.: Clinical utility of C-reactive protein to predict treatment response during cystic fibrosis pulmonary exacerbations. PLoS One. 2017; 12(2): e0171229. PubMed Abstract | Publisher Full Text | Free Full Text

62. Parkins MD, Rendall JC, Elborn JS: Incidence and risk factors for pulmonary exacerbation treatment failures in patients with cystic fibrosis chronically infected with Pseudomonas aeruginosa. Chest. 2012; 141(2): 485-93. PubMed Abstract | Publisher Full Text 


\section{Open Peer Review}

\section{Current Peer Review Status:}

\section{Editorial Note on the Review Process}

Faculty Reviews are review articles written by the prestigious Members of Faculty Opinions. The articles are commissioned and peer reviewed before publication to ensure that the final, published version is comprehensive and accessible. The reviewers who approved the final version are listed with their names and affiliations.

\section{The reviewers who approved this article are:}

\section{Version 1}

\section{Patrick A. Flume}

Department of Medicine and Pediatrics, Medical University of South Carolina, Charleston, SC, USA Competing Interests: No competing interests were disclosed.

\section{Martin J Wildman}

School of Health and Related Research (ScHARR), University of Sheffield, Sheffield, UK

Competing Interests: No competing interests were disclosed.

\section{John J. LiPuma}

Department of Pediatrics and Communicable Diseases, University of Michigan Medical School, Ann Arbor, MI, USA

Competing Interests: No competing interests were disclosed.

The benefits of publishing with F1000Research:

- Your article is published within days, with no editorial bias

- You can publish traditional articles, null/negative results, case reports, data notes and more

- The peer review process is transparent and collaborative

- Your article is indexed in PubMed after passing peer review

- Dedicated customer support at every stage

For pre-submission enquiries, contact research@f1000.com 